\title{
Scale dependence of bacterioplankton patchiness
}

\author{
Carlos M. Duarte ${ }^{1}$, Dolors Vaqué ${ }^{2}$ \\ ${ }^{1}$ Centro de Estudios Avanzados de Blanes, Camino de Santa Barbara, E-17300 Blanes, Girona, Spain \\ ${ }^{2}$ Instituto de Ciencias del Mar, Paseo Nacional s/n, E-08039 Barcelona, Spain
}

\begin{abstract}
We provide evidence, based on the assessment of bacterial abundance in a series of samples representing geometrically decreasing volumes $(5 \mathrm{l}$ to $0.25 \mathrm{ml}$ ), for the existence and scale dependence of patchiness in mixed-layer marine bacterioplankton. Our results demonstrate the existence of strong bacterioplankton patchiness at centimetre scale, the bacterioplankton community appearing as homogeneous when sampling at larger or smaller scales. We also provide, based on the inferred frequency distribution of bacterial densities, a representation of the in situ spatial distribution of the bacterioplankton population sampled. This distribution depicts the bacterioplankton community as composed of high density $\left(>10^{7}\right.$ bacteria $\mathrm{ml}^{-1}$ ) bacterial patches scattered within a 'matrix' of low bacterial density $\left(10^{5}\right.$ bacteria $\left.\mathrm{ml}^{-1}\right)$. These results imply that the processes regulating bacterial abundance operate at centimetre scale.
\end{abstract}

\section{INTRODUCTION}

The abundance and spatial distribution of marine organisms is inferred from samples collected with devices that capture 10 to $10^{3}$ organisms per sample (Fig. 1). However, bacterioplankton ecologists collect disproportionately large samples, containing $10^{8}$ to $10^{10}$ bacteria per sample (Fig. 1). The vast number of organisms contained within individual bacterioplankton samples precludes the detection of patchiness. Whether organisms appear aggregated or not depends on sampling scale (Wiens 1989), large samples decreasing the power to detect aggregated distributions (Pinel-Alloul et al. 1989). Thus, the smallscale homogeneity assumed in most bacterioplankton studies may be an artifact derived from the use of inadequate observational scales, and should be reconsidered. This is particularly necessary because recognition of the importance of interactions between microorganisms in controlling bacterioplankton dynamics (Azam et al. 1983, Sherr \& Sherr 1987, Hagstrom et al. 1988, Vaqué et al. 1989) has created an explicit demand to increase our knowledge of the spatial distribution of bacterioplankton at the scales at which these interactions occur (Mitchell \& Fuhrman 1989).

We examine here the scale dependence of patchiness for the (free) bacterioplankton population of
Alfacs Bay (Ebro Delta, NW Mediterranean), a tideless, nutrient-poor estuarine embayment (Camp \& Delgado 1987, Delgado \& Camp 1987). Our approach

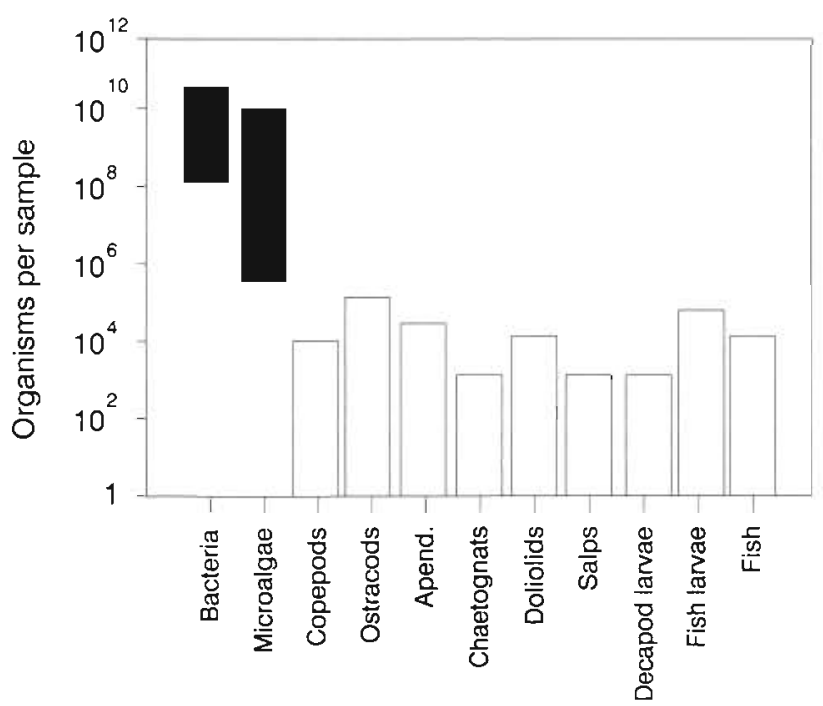

Fig. 1. Range of the number of organisms contained in single samples collected using the most common sampling gear for each taxa. Ranges were provided by scientists from the Instituto de Ciencias del Mar (Drs Ana Sabates, Miquel Alcaraz, Xavier Fuste, Dolors Vaqué, Marta Estrada, Pilar Andreu, and Isabel Trepat) studying the abundance of the different taxa in the Mediterranean and Atlantic 
to detecting aggregation at scales below the usual sample size (5 to 30 l) was to measure bacterial density in a series of replicated samples with geometrically decreasing volumes $(5000,2000,500,100,20,10$, 5,1 , and $0.25 \mathrm{ml}$ ). If bacteria were randomly distributed within these scales, the mean density derived from a few (e.g, <5) replicate samples would be expected to be conservative along the sample series. However, if bacteria were aggregated within the scales covered, the average density derived from a few replicate samples will decrease upon reaching a sampling volume smaller than that necessary to capture a single bacterial patch (i.e. the scale at which the probability of capturing at least 1 bacterial patch becomes small). This, of course, represents a shift in the perceived mean bacterial density and not in the true mean bacterial density. Thus, if the number of replicate samples collected along the volume series were large $(>30)$, the average density would remain conservative but its frequency distribution would increasingly become positively skewed as the scales at which aggregation occurs are approached.

\section{MATERIAL AND METHODS}

Sampling was conducted from an outboard motor boat on 26 June 1988. Subsurface (ca $0.2 \mathrm{~m}$ ) samples were collected from the centre of Alfacs Bay, where temperature and salinity profiles demonstrated physi$\mathrm{cal}$ homogeneity (temperature variation $<0.01{ }^{\circ} \mathrm{C}$ and salinity variation $<0.01 \mathrm{~g} \mathrm{l}^{-1}$ ) above a pycnocline located at a depth of $3 \mathrm{~m}$. We collected 4 replicate samples for each volume in the series to assess variability about the estimated bacterial abundance. Samples $<50 \mathrm{ml}$ were collected directly using sterilized syringes devoid of needles, and transferred to serum-stoppered sterile vials. Larger samples were collected with sterilized, clean cylindric containers which were vigorously shaken before transferring a $20 \mathrm{ml}$ subsample, using sterilized syringes, to a serumstoppéred sterile vial. These vials contained enough formaldehyde to ensure a final concentration of $2 \%$ to preserve the samples. Bacterial abundance was estimated by epifluorescence microscopy (Nikon TMDEF) on one $0.25 \mathrm{ml}$ subsample from each vial. Subsamples were concentrated on $0.2 \mu \mathrm{m}$ Nuclepore filters, pre-stained with Sudan Black, and stained with acridine orange (Hobbie et al. 1977). Bacteria were counted, ca 400 cells for each subsample, at a magnification of $1000 x$.

Because 5 different devices were used to estimate bacterial density depending on sampling volume, we confirmed the comparability of the results obtained by collecting, using all 5 devices, triplicate samples from a marine bacterioplankton community confined in a laboratory mesocosm. The results obtained demonstrated no significant difference in the average bacterial density among sampling devices (multiple TukeyKramer test, $p<0.05$ ), the coefficient of variation of the estimated densities being similar (about $25 \%$ ) for all devices. We also tested whether bacterial adsorption to the walls of the smaller (i.e. $1 \mathrm{ml}$, greater surface/volume ratio) syringes could influence the number of bacteria in the sample. This was done by counting a series of replicated samples circulated through 1 to 4 new syringes. The observed lack of any significant decrease in bacterial density with increasing number of transit though syringes indicates that bacterial adsorption to walls is, at most, smaller than counting error.

\section{RESULTS}

Average bacterial concentration for the natural bacterioplankton population increased significantly ( $>5$ fold; multiple Tukey-Kramer test, $p<0.001$ ) from samples $<5 \mathrm{ml}$ to larger samplos (Fig. 2). Bactcrial distribution was, therefore, highly aggregated because the results deviate greatly from the conservation of the mean expected if bacteria were randomly distributed. Significant changes in bacterial abundance were evident only at the interval between $1 \mathrm{ml}$ and $10 \mathrm{ml}$ (i.e 1 to $2 \mathrm{~cm}$ scale; Fig. 2), and no evidence of patchiness was observed at either smaller or larger scales. This demonstrates that bacterioplankton patchiness is scale-dependent, and further indicates that the abundance of high-density bacterial patches was, in the population sampled, ca 0.1 to $1 \mathrm{ml}^{-1}$.

The inferred centimetre-scale bacterial patchiness was tested by a second experiment which examined the distribution of bacterial density in 50 replicated $1 \mathrm{ml}$

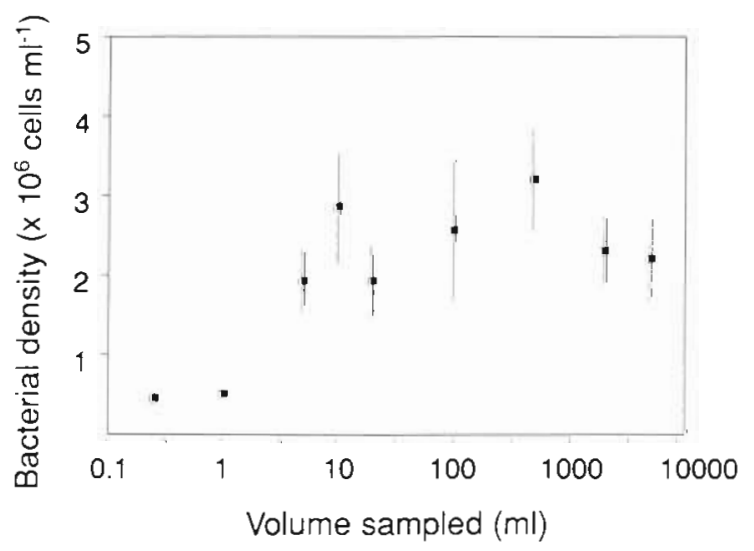

Fig. 2. Average $( \pm 1$ SD) bacterial densities for a range of sampling volumes collected from sub-surface water in Alfacs Bay (Ebro Delta, NW Mediterranean) 
samples collected at the same location. If the reduced bacterial density in samples $<5 \mathrm{ml}$ were attributable to the decreased change of including dense patches, then higher replication (i.e. 50 replicates instead of just 4) should ensure the inclusion of some high-density patches within the replicates. This should be reflected in a skewed distribution of bacterial density in the population of replicated samples. The results obtained (Fig. 3) confirmed the inferred $\mathrm{cm}$-scale patchiness of the bacterial population; the frequency distribution of bacterial density in the 50 replicated $1 \mathrm{ml}$ samples was highly skewed (Fig. 3). The distribution obtained (Fig. 3) depicted the bacterial population as composed of a ramdomly (Poisson) distributed sparse (mode ca $10^{6}$ cells $\mathrm{ml}^{-1}$ ) bacterial population (i.e. the low-density

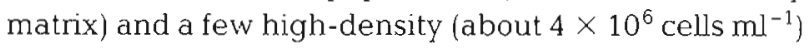
bacterial patches.

We used simulation analysis to infer what the in situ spatial distribution of the bacteria should be to yield the observed results. Nine distributions, representing increasing aggregation, were simulated by generating random, log-normally distributed bacterial abundances with mean equal to the asymptotical value attained at large sample volumes (between 2 and $3 \times$ $10^{6}$ cells $\mathrm{ml}^{-1}$; Fig. 2) and standard deviations ranging from 2 - to 12 -fold the mean value. For each distribution, the abundance expected at the different sampling volumes was estimated by dividing the sample into $0.25 \mathrm{ml}$ units (the smallest volume sampled here) and then assigning random bacterial abundances, sampled from the distributions tested, to each unit. This procedure was repeated 200 times to estimate the variance for each sampling volume and distribution.

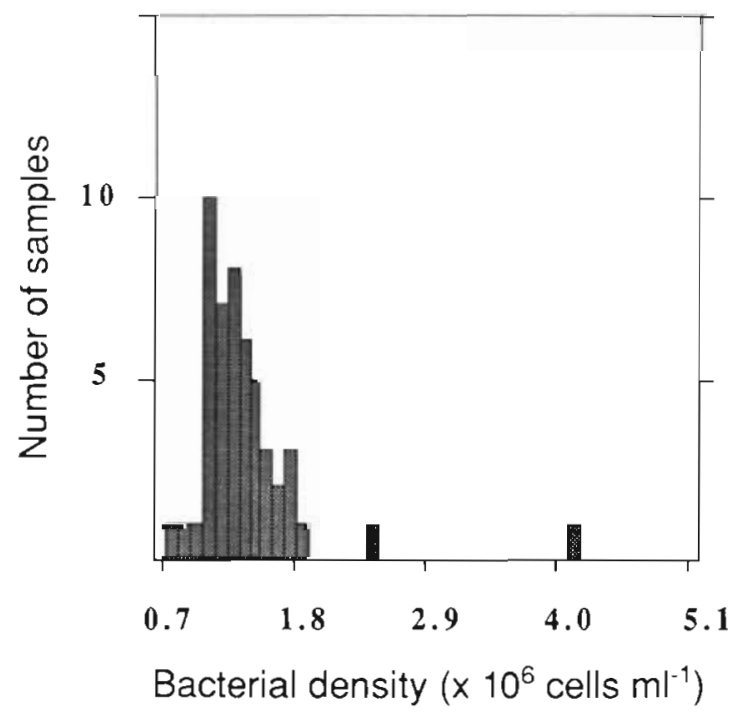

Fig. 3. Frequency distribution of bacterial density in 50 replicated $1 \mathrm{ml}$ samples collected in Alfacs Bay (Ebro Delta, NW Mediterranean)
The observed changes in bacterial abundance with increasing sample size (Fig. 2) could be closely reproduced $\left(R^{2}=0.84\right.$, slope $=1.21 ;$ Figs. $\left.4 \& 5\right)$ when sampling from a bacterial population showing great spatial variability (coefficient of variation $=800 \%$ ) and skewness (log-normal distribution; Figs. 4 to 6). Moreover, the simulated frequency distribution of bacterial density (Fig. 6) closely resembled that obtained after sampling 50 replicated $1 \mathrm{ml}$ samples (Fig 3). The corresponding spatial distribution (Fig. 6) depicts the bacterioplankton community observed as composed of high density $\left(>10^{7}\right.$ bacteria $\left.\mathrm{mi}^{-1}\right)$ bacterial patches scattered within a 'matrix' of low bacterial density $\left(10^{5}\right.$ bacteria $\left.\mathrm{ml}^{-1}\right)$, corresponding to that found in sampling volumes $<1 \mathrm{ml}$ (Fig. 2).

\section{DISCUSSION}

The plausibility of patchiness at the scales (1 to 2 $\mathrm{cm}$ ) observed here has been intensively debated in the past (Levin \& Segel 1976, Lehman \& Scavia 1982, Azam \& Ammerman 1984, Fenchel 1984, Sieburth

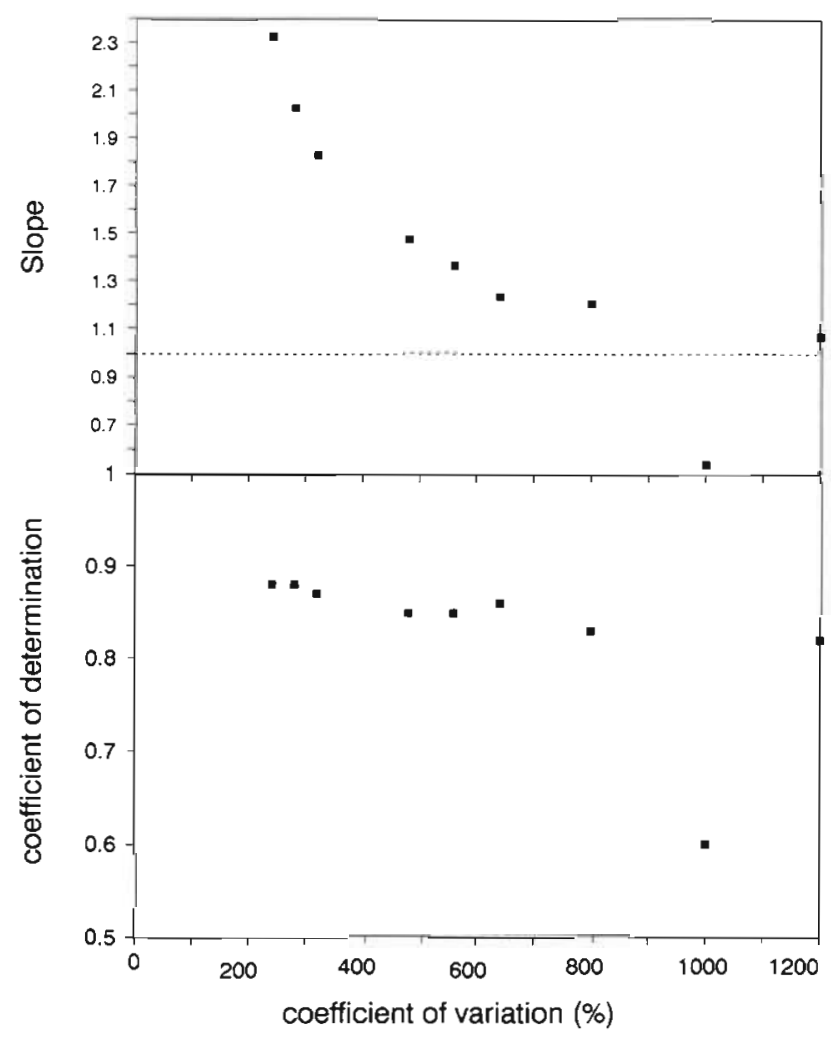

Fig. 4. Coefficient of determination and regression slope for linear regressions between the average bacterial abundance observed at different sampling volumes (Fig. 2) and those expected from simulated populations showing different degrees of aggregation (i.e. coefficient of variation) 


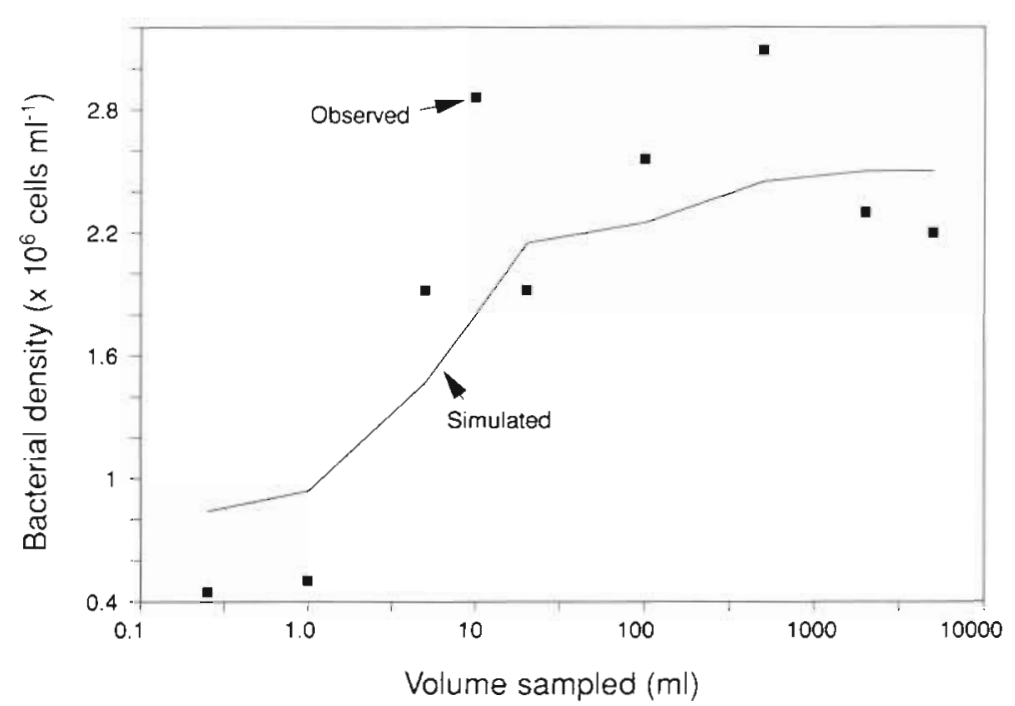

Fig. 5. Relationship between the average bacterial densities observed for a series of sampling volumes and those expected for a log-normally distributed population with a standard deviation 8-fold greater than the mean

1984). It was initially assumed that patchiness of free-living organisms at cm-scale would be prevented by the dissipative influence of turbulent and molecular diffusion (cf. Okubo 1980). However, the occurrence of microscale patchiness in planktonic organisms in the ocean appears widespread (Owen 1989), and recent advances in small-scale ocean physics have suggested a number of possible complementary mechanisms for the persistence of patchiness at $\mathrm{cm}$-scale.

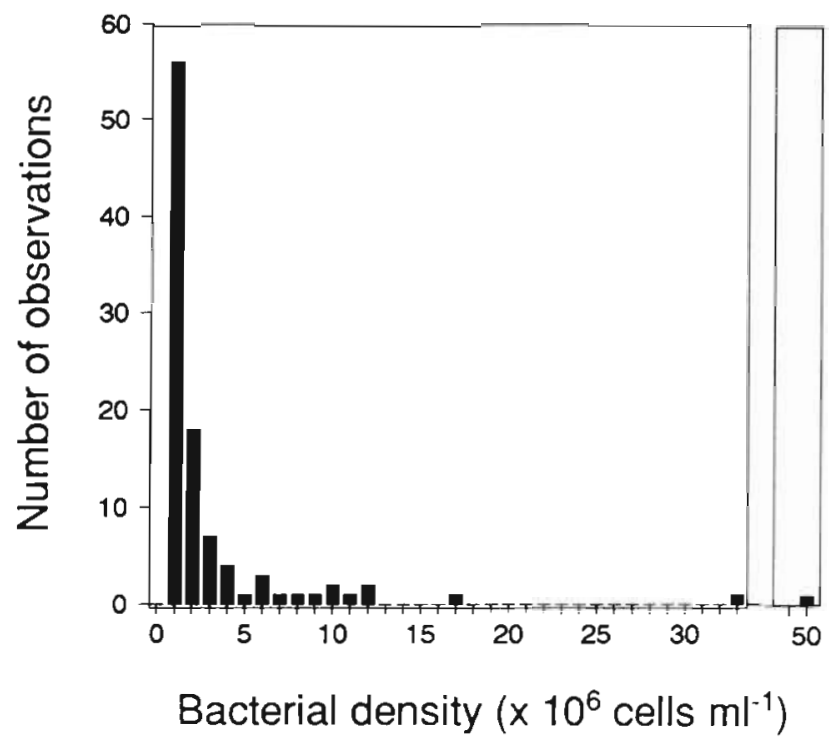

First, because the importance of turbulent diffusion decreases considerably below the inertial subrange $(0.1$ to $1 \mathrm{~m}$; Powell et al. 1975. Mackas et al. 1985, Soloviev et al. 1989, Lazjer \& Mann 1989), organisms less than $100 \mu \mathrm{m}$ in size should experience little dispersion by turbulence. As a second mechanism, coagulation of excreted organic matter may reduce dispersion by increasing water viscosity and reducing turbulence drag by elastic effects (Jenkinson 1986). Third, boundary layers surrounding individual cells and algal filaments provide turbulence-free environments (Lazier \& Mann 1989), as suggested by reports of bacterial clustering around phytoplankton cells (Azam \& Ammerman 1982). Paradoxically, these effects may be even enhanced in turbulent environments because of DOC coagulation on bubbles (Kepkay \& Johnson 1989), a tendency towards increased mucus production by phytoplankton in turbulent environments (Fryxell et al. 1985), and the dispersion of large patches into progressively smaller patches by small-scale flow irregularities (Owen 1989). The relative importance of these mechanisms is still unknown; however, the net result of their combined actions should be increased bacterial patchiness. Yet the question of whether the apparently free bacteria enumerated here were actually free in nature or whether a fraction of these bacteria were included into fragile aggregates that dispersed during sampling remains

Fig. 6. The inferred frequency distribution (left) and spatial representation (right) of the bacterial population in situ. This representation was constructed by filling a 2-dimensional space with simulated bacterial densities sampled from the distribution best approaching the results in Fig. 2 (cf. Figs. 4 \& 5). Increasing shadings of grey represent, respectively, bacterial densities below $10^{6}$ cells ml-1, between $10^{6}$ and $10^{7}$ cells ml ${ }^{-1}$, and greater than $10^{\prime}$ cells ml $\mathrm{ml}^{-1}$ 
unresolved. Moreover, the scale of bacterial patchiness found here (1 to $2 \mathrm{~cm}$ ) may well vary depending on environmental conditions, as suggested by reports of a close relationship between the extent of patchiness of small planktonic organisms and wind speed (Owen 1989).

The finding of intense bacterial patchiness at $\mathrm{cm}^{-}$ scale has important implications for understanding the dynamics of natural marine bacterial populations. First, it suggests the existence of small-scale growth differences, the low density matrix probably representing slow growing or inactive bacteria and the high density patches being generated by fast growing bacteria. The patchiness described also explains the tight control of bacterial populations by grazers, because grazing on high density bacterial patches instead of distant, randomly distributed bacteria should yield a greater grazing efficiency (Azam \& Ammerman 1984, Sherr \& Sherr 1987), particularly for filter feeders (Fenchel 1984). Further, the remarkable constancy over time of bacterial numbers in aquatic ecosystems emphasized by many authors (Azam et al. 1983, Fenchel 1984, Wright \& Coffin 1984) may be partially an artifact derived from the use of sampling scales inadequate to examine bacterial population dynamics. The use of an observational scale 3 orders of magnitude above that at which growth variance occurs should buffer any, potentially large, changes if rapid bacterial growth within some patches is compensated by the depletion of bacteria in other patches by grazers.

The demonstration of scale-dependent bacterial patchiness emphasizes the important implications of the choice of scale of observation in studies of bacterioplankton dynamics, particularly because this choice determines what we can know about the system studied (Allen \& Starr 1982, Wiens 1989). Although the dominant scales of bacterial patchiness may vary among locations, the remarkable similarity in bacterial dynamics among systems (Azam et al. 1983, Wright \& Coffin 1984, Hagstrom et al. 1988) suggests that population elsewhere may show similar patterns. Revision of sampling strategies to use sampling scales 10-fold greater than the estimated patch size (Atkinson et al. 1987) should, therefore, contribute to approximate the scales of observation to those relevant for the reliable description of bacterial processes and to develop a new perspective of bacterial population dynamics.

Acknowledgements. This research was supported by a CICYT grant (project MAR-91-503) to C.M.D. We thank J. Camp and I. Trepat for field and technical assistance, respectively, $F$. Vallespinos for encouragement and advice, and M. Alcaraz, M. Estrada, J. G. Mitchell, C. Pedros-Alio, and 3 anonymous reviewers for comments on the manuscript.

\section{LITERATURE CITED}

Allen, T F. H., Starr, T B. (1982). Hierarchy: Perspectives for ecological complexity. Univ. Chicago Press, Chicago

Atkinson, M. J., Berman, T., Allanson, B. R., Imberger, J (1987). Fine-scale oxygen variability in a stratified estuary patchiness in aquatic environments. Mar. Ecol. Progr. Ser 36: $1-10$

Azam, F., Ammerman, J W. (1982). Growth of free-living marine bacteria around sources of dissolved organic matter. EOS 63: 54

Azam, F., Ammerman, J. W. (1984). Cycling of organic matter by bacterioplankton in pelagic marine ecosystems: microenvironmental considerations. In: Fasham, M. J. R. (ed.) Flows of energy and materials in marine ecosystems. Plenum Press, New York, p. 345-360

Azam, F., Fenchel, T., Field, J. G., Gray, J. S., Meyer-Reil, L. A., Thingstad, F. (1983). The ecological role of water-column microbes in the sea. Mar. Ecol. Prog. Ser. 10: 257-263

Camp, J., Delgado, M. (1987). Hidrografía de las Bahías del Delta del Ebro. Investigación Pesq. 51. 351-369

Delgado, M., Camp, J. (1987). Abundancia y distribución de nutrients en las bahías del Delta del Ebro. Investigación Pesq. 51: 427-441

Fenchel, $\Upsilon$. (1984). Suspended marine bacteria as a food source. In: Fasham, M. J. R. (ed.) Flows of energy and material in marine ecosystems. Plenum Press, New York, p. 301-316

Fryxell, G. A., Gould, R. W. Jr, Balmori, E. R., Thernot, E. C. (1985). Gulf Stream warm core rings: phytoplankton in two fall rings of different ages. J. Plankton Res. 7: 339-364

Hagstrom, A., Azam, F., Andersson, A., Wikner, J., Rassoulzadegan, F. (1988). Microbial loop in an oligotrophic pelagic marine ecosystem: possible roles of cyanobacteria. Mar. Ecol. Prog. Ser. 49: 171-178

Hobbie, J. E., Daley, R. J., Jasper, S. (1977). Use of nuclepore filters for counting bacteria by epifluorescence microscopy. Appl. environ. Microbiol. 33: 1225-1228

Jenkinson, I. R. (1986). Oceanographic implications of nonnewtonian properties found in phytoplankton cultures. Nature, Lond 323: 435-437

Kepkay, P. E., Johnson, B. D. (1989). Coagulation on bubbles allows microbial respiration of oceanic dissolved organic carbon. Nature, Lond. 338: 63-65

Lazier, J. R. N., Mann, K. H. \{1989\}. Turbulence and the diffusive layers around small organisms. Deep Sea Res. 36: $1721-1733$

Lehman, J. T., Scavia, D. (1982). Microscale patchiness of nutrients in plankton communities. Science 216: 729-730

Levin, S. A., Segel, L. A. (1976). Hypothesis for origin of planktonic patchiness. Nature, Lond. 259:659

Mackas, D. L., Denman, K. L., Abbott, M. R. (1985). Plankton patchiness: biology in the physical vernacular. Bull. mar Sci. 37: 652-674

Mitchell, J, G., Fuhrman, J A. (1989). Centimetre scale vertical heterogeneity in bacteria and chlorophyll a. Mar Ecol. Prog. Ser. 54: 141-148

Okubo, A. (1980). Diffusion and ecological problems: mathematical models. Springer-Verlag, New York

Owen, R. W. (1989). Microscale and finescale variations of small plankton in coastal and pelagic envionments. J. mar. Res. 47: 197-240

Pinel-Alloul, B., Downing, J A., Perusse, M., Codin-Blumer, G. (1989), Spatial heterogeneity in freshwater zooplankton: variation with body size, depth, and scale. Ecology 69: 1393-1400

Powell, T M., Richerson, P. J., Dillon, T M., Agee, B. A., Dozier, B. J., Godden, D. A., Myrup, L. O. (1975). Spatial 
scales of current speed and phytoplankton biomass fluctuation in Lake Tahoe. Science 189: 1088

Sherr, E. B., Sherr, B. F. (1987). High rates of consumption of bacteria by pelagic ciliates. Nature, Lond. 325: $710-711$

Sieburth, J M. (1984). Protozoan bacteriovory in pelagic marine waters. In: Hobbie, J. E., Williams, P. J. LeB. (eds.) Heterotrophic activity in the sea. Plenum Press, New York, p. $405-444$

Soloviev, A. V., Vershinsky, N. V., Bezverchnii, V. A. (1989).

This article was submitted to the editor
Small-scale turbulence measurements in the thin surface layer of the ocean. Deep Sea Res. 35: 1859-1874

Vaqué, D., Duarte, C. M. Marrasé, C. (1989). Phytoplankton colonization by bacteria: encounter probability as a limiting factor. Mar. Ecol. Prog. Ser. 54: 137-140

Wiens, J. A. (1989). Spatial scaling in ecology. Funct. Ecol. 3: $385-397$

Wright, R. T., Coffin, R. (1984). Measuring microzooplankton grazing on planktonic bacteria by its impact on bacterial production. Microb. Ecol. 10: 137-149

Manuscript first received: August 21, 1990

Revised version accepted: May 14, 1992 